\title{
WYKOPALISKA $Z$ MARI A STARY TESTAMENT
}

uwarunkowany jest osiągnięciami archeologii, tym - co dziśs powszechnie nazywa się, ,renesansem orientalnym“.

Istotnie też ostatnie stulecie - to okres intensywnych badań archeologicznych na Wschodzie i zdumiewających, rewelacyjnych wprost $\mathrm{w}$ tej dziedzinie rezultatów. Tell el-Amarna, Ras Szamra (dawniejsze Ugarit), Ur, Nippur, Babilon, Mari, Niniwa, Jeryho, Tell el-Hesy, Gezer, Tell Duweir (dawneLakhisz), Qirbet Qumrân — to niektóre, ważniejsze tylko etapy tego stulecia, które André Parrot, kierownik ekspedycji archeologicznej w Mari nazwał słusznie ,un siècle d’orientalisme“ ${ }^{1}$ ).

Dokonywane z coraz wiekszym rozmachem ciagle nowe odkrycia stwarzają szerokie perspektywy dla biblistyki, która rychło poznała w archeologii swego walnego sprzymierzeńca. W miare, jak odkrycia te i liczne wykopaliska archeologiczne wydzierają ziemi ukryte tajemnice przeszłości, jak raz po raz odkopany pomnik sprzed kilku tysiącleci przed Chr. rozświeca. nieznane dotąd bliżej zamierzchłe epoki, coraz natarczywiej narzuca się pytanie, w jakim stoją one stosunku do Biblii, mówiącej o wydarzeniach, jakie miały miejsce w czasach tak odległych na tamtych właśnie terenach rozkopywanych dziś kilofem archeologa.

$\mathrm{Na}$ przestrzeni czasu pomiędzy wydaniem pionierskiego dzieła F. Vigouroux, La Bible et les découvertes modernes en Egypte et en Assyrie (wydanie 1. w 2 tomach w r. 1877, wyd. 6. w 4 t. w r. 1896) aż po ostatnio wydana przez J. B. Pritchard'a znakomitą prace Ancient Near-Easten Texts relating to the Old Testament ${ }^{2}$ ) coraz częściej pojawiały się wartościo-

1) La Bible et l'Orient, Travaux du Premier Congrès d'Archéologie et d'Orientalisme Bibliques (Cahiers de la Revue d'Histoire et de Philosophie Religieuses, nr 34), Paris 1955, s. 2. - Jest to cykl referatów wygłoszonych przez specjalistów-archeologów na kongresie archeologii biblijnej i orientalistyki odbytym w Saint Cloud 23-25 IV 1954. Referat A. Parrot'a, zamieszczony $w$ streszczeniu na s. $117-120$ był okazją do napisania niniejszego artykułu.

2) Second edition corrected nad enlarged, Princeton, N. J., 1955 (zob. recenzja w Biblica 37 (1956) $365 \mathrm{nn}$ ). I wyd. w r. 1950 - zob. res. 
we publikacje zestawiające archeologiczny materiał paralelny do Starego Test. i omawiające ich wzajemny stosunek ${ }^{3}$ ).

Dziś jest już rzeczą nie ulegającą wątpliwości, że doku-menty dotąd wydarte ziemi rzucają nowe światło na księgi Starego Testamentu i na tło wydarzeń, o których one mówią. Okazuje się bowiem, że odgrzebane ,z otchłani wieków“ tabliczki pokryte pismem klinowym potwierdzają w całej rozciągłości dane biblijne ${ }^{4}$ ).

Dotyczy to również wykopalisk z M ari w Mezopotamii. Przemówiły i znad brzegów Eufratu dawne obumarłe, a raczej uśpione tylko cywilizacje, dając głośne świadectwo, które A. Parrot nie waha się nazwać ,orędziem przeszłości“5), a po-

w RBL 7 (1954) 275 n oraz w Biblica 32 (1951) 454-458. Dzieło to, powszechnie znane pod skrótem ANET, analogicznie do dzieła H. Gressmann'a (v. uw. 3) ma swój odpowiednik w The Ancient Near East in Pictures relating to the Old T. (tegoż autora), Priceton, N. J., 1954, v. rec. V. D. 33 (1955) 348 n.

3) Warto podać chociażby niektóre:

A. Jirku, Altorientalischer Kommentar zum Alten Testament, Liepzig 1923; H. Gressmann, Altorientalische Texte und Bilder zum Alten Test., T. I.: A. O. Texte ${ }^{2}$, Berlin u. Leipzig 1926, T. II.: A. O. Bilder zum A. T.2, Berlin u. Lp 1927 (obiektywne zestawienie materiału). - Ch. Marston, The new knowledge about the Old Testament, London 1933 (Dzieỉo to później M. rozszerzył w obszerniejszym oprac, The Bible is true, które L. Clarence wydał po francusku: La Bible a dit vrai, Résultats des fouilles effectuées de 1924 à 1934 en terre biblique, Paris 1934); R. De Langhe, Les Textes de Ras Shamra-Ugarit et leur rapports avec le milieu biblique de l'Ancien Test., T. I-II, Paris 1945. Cenne są prace wybitnego archeologa naszych czasów William Foxwell Albright'a: Archeology and the Religion of Israel, Baltimore 1946; Id., The Archeology of Palestine, London 1949; Id., From the Stone Age to Chistianity, I. wyd. ma 3 przedruki: 1940, 1941 i 1942, II. wyd. 2 przedruki: 1946 i 1948.

Poza tym: A. Parrot, Découverte des mondes ensevelis, NauchâtelParis 1952 (Iszczególnie rozdział „Passé biblique et son milieu oriental“, str. 121-136); Merrill F. Unger, Archeology and the Old Testament, Grand Rapids (Michigan) 1954, i i.

4) Por. np. W. F. Albright, From the Stone Age to Christianity, Baltimore 1946, s. 43; Ks. W. Michalski, Starożytne Dzieje Biblijne, Kraków 1912, s. 13; Ks. E. Dąbrowski, Glossy i odkrycia biblijne, Warszawa 1954, s. 33 n.

5) Découverte des mondes ensevelis, Neuchâtel-Paris 1952, 37. 
twierdzają prawdziwość relacji biblijnych, oddały nam równocześnie „duszę narodów“, które już dawno zniknęły z widowni dziejów" ${ }^{6}$ ).

Wykopaliska archeologiczne w Mari nad środkowym Eufratem rozpoczęto w r. 1933. W sierpniu tegoż roku Beduini zamierzający przy wzgórzu Tell Hariri pochować umarłego członka swego szczepu, przy końcu kopania grobu natrafili na starożytną statuę z napisem klinowym. Było to hasłem do podjęcia prac archeologicznych. Na czele ekspedycji naukowej stanął francuski uczony André P a r rot. Ruch Bibl. i Lit. w art. Ks. J. Jelito ${ }^{7}$ ) a częściowo i w art. prof. J. Wolskiego ${ }^{8}$ ) informował już krótko o tym. - W wyniku przeprowadzonych badań okazało się, że w miejscu, o którym mowa, było pogrzebane starożytne miasto Mari - kwitnący już w 3. tysiącleciu ośrodek kulturalny i handlowy, o którym wspominały także odkryte w r. 1887 teksty z Tell el-Amarna w Egipcie oraz teksty babilońskie, mówiące o jego zniszczeniu przez wojska Hammurabiego.

Miasto to, mając idealne położenie na ważnym szlaku wiodącym wzdłuż Eufratu aż do zatoki Perskiej, na zachód zaś ku portom Morza Śródziemnego, utrzymywało ożywione stosunki handlowe, polityczne i kulturalne nie tylko z państwem Babilończyków, ale i z światem egejskim (Kreta, Cypr), z portami Syrii i Fenicji (np. już z epoki tzw. średniego bronzu znane nam sa kontakty z Ugarit). Było więc Mari ważnym handlowym i strategicznym punktem na drodze z dolnej Mezopotamii do Syrii, było miastem królewskim o ludności semickiej ${ }^{9}$ ). Jego historia obejmuje długi okres na przestrzeni od 3000 lat przed Chr. aż po erę chrześcijańską. Co prawda zostało ono zniszczone w XVIII w. przed Chr., gdy jego ostatni

$\left.{ }^{6}\right)$ Tamże; zob. str. 121-136.

$\left.{ }^{7}\right)$ Ks. J. Jelito, Syria w czasach przedhellenistycznych, RBL 5 (1952) $11-34$.

s) J. Wolski, Wschód starożytny w. świetle najnowszych bađ̄ań, RBL 5 (1952) 109-141 i 218-239.

9) Por. K.s. J. Jelito, art. cyt., s. 13; J. Wolski, art. cyt., s. 117; A. Parrot, Mari et l'Ancien Testament, La Bible et l'Orient, Paris 1955, s. 117. - Zob. mapki w RBL 5 (1952) 15. 115. 
władca Zimri-lim, poprzedni sojusznik a późniejszy przeciwnik Hammurabiego podniósł przeciw niemu głowę. Jednakże nie nikną bynajmniej od razu wszelkie ślady; tak np. Asyryjczycy urządzają tam jeszcze swe garnizony, a w epoce Seleucydów jawią się nowi koloniści. Żołnierze Hammurabiego po zdobyciu Mari splądrowali je i spalili pałac Zimri-lim'a pochodzący z końca 3. tysiąclecia. Mury tego pałacu, który wybitny archeolog O. L. H. Vincent nazwał klejnotem starożytnej architektury orientalnej ${ }^{10}$ ), sięgające wysokości $4-5 \mathrm{~m}$ (wysokość dotąd $\mathrm{w}$ archeologii niespotykana) zachowały się jeszcze w części. Właśnie w jednym z licznych pokoi (ponad 300) tego pałacu odnaleziono zasobne archiwum królewskie liczące ok. 20000 tabliczek $^{11}$ ). W skład jego wchodzi bogata korespondencja zredagowana $\mathrm{w}$ j. akkadyjskim i piśmie klinowym oraz teksty ekonomiczne, jak umowy i traktaty handlowe oraz dekrety dotyczące stosunków gospodarczych. Odkryte dokumenty z Mari zarówno epigraficzne jak i-archeologiczne (materiał pisany i niepisany) dają nam wgląd w tajniki starożytnego centrum kwitnącej przed wiekami cywilizacji o charakterze zachodnio-semickim, współczesnej epoce patriarchów, pozwalają. nam lepiej poznać warunki i tło epoki Hammurabiego, współczesnego biblijnemu Abrahamowi ${ }^{12}$ ). Dziś jest już rzeczą nie podlegającą dyskusji, że zachodzący w Gen 14, 1. 9 Amraphel melekh — Si'ar — to nikt inny, jak właśnie Hammurabi (Ham murapi, Ammurapi-ilu) wymieniany w odkrytych tekstach król Babilonu nazywanego również krainą Sinear (Senaar) ${ }^{13}$ ).

10) Zob. Revue Biblique 48 (1939) 156.

11) Dokumenty te są $w$ trakcie opracowywania i publikacji w ramach kolekcji „Les textes cunéiformes du Louvre“. Tom I, opublikował w r. 1946 w Paryżu znany filolog G. Dossin pt. ,Les archives royales de Mari".

12) A. Parrot, art. cyt., s. 117; Syria 20 (1939) $97 \mathrm{nn}$.

13) W. Gronkowski, Współczesność Abrahama z Hammurapim, Poznań 1927; P. E. Dhorme, Hammourabi-Amraphel, Revue Bibl. 5 (1903) 205-226; Tenże: Abraham dans le cadre de l'histoire, R. B. 37 (1928) 367-385; 481-511; L. Pirot, art. „Abraham“ w Supplément do Dictionnaire de la Bible, I, col. 11-28; E. Kalt, Biblische Reallexikon, I., Paderborn 1938, col. 90; 750 n; J. de Fraine, De chronologia Abrahae secundum documenta nuperrime effossa, V. D. 26 (1948) 104-109. 
W tekstach z Marii zachodzi również imię Arriwuk (wzg1. Arriwaz), które według wszelkiego prawdopodobieństwa należy zidentyfikować z imieniem 'Ariôkh, które spotykamy również w Gen 14, 1 jako imię króla Larsy (w T. M. melekh 'Ellasar na wschód od dolnego Eufratu pomiędzy Erech a Ur), będącego także w koalicji Hammurabiego.

Historyczność całego zresztą epizodu Gen 14, 1-24, wokół którego głośne swego czasu toczyły się dyskusje, dzięki tekstom z Mari znajduje wymowne potwierdzenie. Dowiadujemy się z nich np., że Elam, o którego królu Kedar-Lahomerze także jest mowa w Gen 14, za czasów Hammurabiego wysłało silny kontyngent wojska do górnej Mezopotamii (Subartu). Nieco wcześniej Elamita Kudur-Mabuk panował w Babilonie, a dwóch swych synów osadził na tronie królewskim w Larsa ${ }^{14}$ ). Kontakty i wpływy Elamu na ziemie Kanaanu wydawały się dawniej wielu krytykom nieprawdopodobne, i dopiero potrzeba było tekstów z Mari, które i na tym punkcie potwierdziły relacje. biblijne.

Co do korelacji imion wypada jeszcze wspomnieć, że Charles F. J e a n należący również do grupy ekspertów (w sekcji filologicznej) zajmujących się wykopaliskami z Mari, na francuskim kongresie archeologii i orientalistyki biblijnej odbytym w SaintCloud w dniach 23-25 IV 1954 poświęcił specjalne studium imionom własnym osób w listach z Mari i w najstarszych tekstach Pięcioksięgu ${ }^{15}$ ). Obok ciekawych spostrzeżeń natury gramatycznej, w których wykazuje podobieństwo w tworzeniu i budowie filologicznej imion zachodzacych w Pięcioksięgu oraz imion spotykanych w tekstach z Mari ważnym wydaje mi się jego stwierdzenie, że analiza porównawcza imion w dokumentach pisanych Pięcioksięgu wykazuje, iż są one pisane w ten sam sposób; fakt zaś, że nawet później, w różnych epokach

14) Zob. A Catholic Commentary on Holy Scripture (dzieło zbiorowe), London...-New York 1953, s. 194; R. De Vaux, Les patriarches hébreux et les découvertes modernes, Revue Bibl. 53 (1946) 328-349.

15) Les noms propres de personnes dans les lettres de Mari et dans les plus anciens textes du Pentateuque, w "La Bible et l'Orient", dz. cyt., s. $121-128$. 
imiona te spctykamy w tej samej formie, tym wyraźniej świadczy o wiernym ich przechowaniu ${ }^{16}$ ). Badania imion tekstów. z Mari mówią ponadto, że pomimo iż językiem tych tekstów jest. niemal wyłącznie j. akkadyjski, to jednak znaczna ilość tych imion jest pochodzenia amoryckiego. Język bowiem jako taki prędzej ulega wpływom obcym niż imiona. Pomimo więc, iż Amoryci po inwazji na ten teren przejęli jego język, to jednak. zachowali amorycki charakter swych imion.

Teksty z Tell el-Hariri-Mari, podobnie już przedtem odkrycia dokonane w Ras Szamra-Ugarit rzucają również nowe światło na chronologię epok starożytnego Wschodu i domagają się przesunięcia datacji panowania Hammurabiego, a w konsekwencji także epoki patriarchy Abrahama o \pm 200 lat później. Badania synchronizacyjne bowiem tekstów z Mari wykazały, że król asyryjski Szamszi-Adad I. objął władzę nad Asyrią przed babilońskim królem Hammurabim. Szamszi-Adad panował bowiem równocześnie z Jahdunlim, królem miasta Mari, zaś syn pierwszego: Jasmah-Adad panował przez pewien czas w Mari po śmierci Jahdumlim'a, a syn tegoż - wspomniany już Zimrilim był sprzymierzeńcem, a później przeciwnikiem Hammurabiego i panował na pewno w w. XVIII ${ }^{17}$ ). Abstrahując od pewnych — niewielkich zresztą rozbieżności wśród poszczególnych uczonych w dokładnym ustaleniu daty panowania Hammurabiego - współczesnego Abrahamowi - najpowszechniej (za Poebl'em) przyjmuje się lata $1728-1686$ przed Chr. ${ }^{18}$ ).

$\left.{ }^{16}\right)$ Art. cyt., s. 121. - Przytoczmy parę przykładów:

1) Szim‘î: Ex 6, 17; 2 Król 16, 5; 3 Król 1, 8; 1 Kron 4, 26; 2 Kron 31, 12; Ezdr 10, 23; Est 2, 5 .

2) Jiszma'el: Gen 16, 11; Jer 40, 1; 4 Król 25, 23; 1 Kron 8, 38; F.zdr 10, 22.

3) Netan'el: Liczb 1, 8; 1 Kron 2, 14; 15, 24; 2 Kron 17, 7; Ezdr 10, 22; Neh 12, 21; (por. Jn 21, 2).

4) Mîsza'el: Ex 6, 22; Dan 1, 6; Neh 8, 4.

5) Haran: Gen 11, 26; 1 Kron 23, 9; - i wiele in.

${ }^{17}$ ) Por. Ks. Jelito, art. cyt., s. 19; J. Wolski, art. cyt., s. 235 . Postulat przesunięcia daty wysunął już G. Contenau, Manuel d’archéologie orientale, t. II, Paris 1931, $820 \mathrm{nn}$.

${ }^{18)}$ W. F. Albright jako początek jego panowania podaje ok. 1870; Ungnad: 1801-1759; Siderský 1848-1800. - Zob. Ks. Jelito, art. cyt., 
W tekstach z Mari, zwłaszcza w korespondencji króla Zimrilim'a (podobnie jak już i w dokumentach z Tell el-Amarna, Ras Szamra i Boghazköi) spotykamy również od dawna wszechstronnie dyskutowaną nazwę Habiru (Hapiru).

Dziś jeszcze - po kilkudziesięciu latach badań — jest to jak to określił Jean Bottéro - „un problème irritant“ ${ }^{19}$ ).

$\mathrm{Na}$ podstawie tekstów klinowych z Mari jest rzeczą stwierdzoną, że Habiru żyli również w Mezopotamii; znajdujemy ich ponadto w Syrii i Palestynie, a w okresie 19-20 dynastii także w Egipcie, gdzie występują również pod nazwą ' $p r w$, ' $p w r j^{20}$ ). Teksty $z$ Mari, podobnie jak i dokumenty z Ras Szamra pomogły też walnie w identyfikacji ideograficznej formy Sa. Gaz z omawianymi Habiru, tych zaś z grupą ludności, której Hebrajczycy byli częścią składową ${ }^{21}$ ).

Szereg razy w dokumentach z Mari znajdujemy też grupe ludnościową określoną jako „Bene Jamina“.

Z tekstów wynika, że są to nomadzi, wzgl. półkoczownicy, pojawiający się w północnej strefie Mari. A. Parrot wysuwa w związku z tym hipotezę migracji tego szczepu (byłby to jego zdaniem klan Beniamitów) z południa w kierunku północnym, analogicznej do wędrówki rodziny Teraha (Gen 11, 31), która z Ur poprzez Haran zdążała do Kanaanu ${ }^{22}$ ).

Wiemy z Biblii, że w Haran osiadł brat Abrahama Nahor.

s. 19. - Są jednak uczeni (do których zalicza się też A. Parrot), którzy przesunięcia datacji nie uważają za konieczne.

${ }^{19}$ ) Le problème des Habiru à la 4-me Recontre Assyriologique Internationale (Cahiers de la Societé Asiatique XII) Paris 1954, s. V. Zob. też René Follet, Un défi de l'Histoire: Les Habiru, Biblica 36 (1955) $510-513$.

${ }^{20}$ ) Por. m. in. Nova documenta de Habiru, Biblica 33 (1952) $561 \mathrm{n}$.

¹) Pogląd ten, który w ogniu dyskusji coraz bardziej się krystalizował, przyjął juz w r. 1920 polski uczony: Ks. Wł. Szczepański, Mieszkańcy Palestyny pierwotnej (Studia nad Palestyną $\mathrm{Nr}$ 5), Kraków 1920 , S. 3; 46-48. Por. też Ks. J. Jelito, Abraham-Hebrejczyk, Przegląd Teologiczny 6 (1925) 82-86; Ks. Cz. Jakubiec, Z problematyki księgi Genesis, Początki Izraela (Warszawskie Studia Teologiczne 21), W-wa 1947, s. 46; De Langhe, dz. cyt. T. II, 458 nn; J. Wolski, art. cyt., s. 138.

22) A. Parrot, art. cyt., s. 117. - W tekstach jest także mowa o jakimś sprzymierzeniu zawartym przez Bene-Jamina w Haranie. 
Rozdział 24 księgi Genesis mówi nam, że Abraham, nie chcąc za żadną cenę dopuścić do zmieszania się jego potomstwa z pogańskimi Kananejczykami, tam właśnie do Haran, do swych krewnych wysyła swego sługę Eliezera celem wyszukania małżonki dla syna Izaaka i stamtąd rzeczywiście sprowadza Rebekę. Tam też syn Izaaka Jakub znajduje dla siebie małżonki wśród swych krewnych: Leę i Rachelę (Gen 29).

A. Parrot przypuszcza, że właśnie dla upamiętnienia tych szczęśliwych chwil, jakie Jakub spędził w tym mieście, nadał on swemu najmłodszemu synowi imię Ben-jamin (syn prawicy, syn szczęścia - Gen $35,18{ }^{23}$ ).

Trudno to sprawdzić, bo teksty biblijne bliżej tego szczegółu nie wyjaśniają. Natomiast sama okoliczność, że dokumenty z Mari zdaniem A. Parrot'a sugerują koncepcję szerszych kontaktów potomków Jakuba - Beniamitów z terenem Mezopotamii nie nasuwa - jak sądzę - specjalnych zastrzeżeń, z wykluczeniem wszakże widocznych u Parrot'a tendencji do opowiadania się za eponimicznym pojmowaniem imion zachodzących w St. T. ${ }^{24}$ ).

Na czele owych „Bene Jamina" stała jakaś wysoka osobistość zwana „,davidum" (wódz naczelny). Termin ten filologicznie jest identyczny $\mathrm{z}$ imieniem Dawida. W związku z tym A. Parrot - wskazując na 1 Sam 16, 18; 18, 17 - stawia hipotezę, że wyraz „Dawid“ mógł być pierwotnie tytułem wojskowym, przyniesionym przez Beniamitów przybywajacych z Syrii ${ }^{25}$ ). Trzeba jednak zaznaczyć, że w St. T. „Dawid“ jest wyraźnie imieniem własnym a nie tytułem, i to występującym w odniesieniu do jednej tyḷo, konkretnej osoby — syna Jišaj'a (Jessego), największego obok Salomona króla Izraelitów.

W tekstach z Mari mówiących o „Bene Jamina“ jest wzmiankowany zwyczaj dawania sygnałów za pomocą ognia i pochodni,

$\left.{ }^{23}\right)$ Art. cyt., s. 118. - Matka Rachel nazwała go przedtem Benoni = syn mego cierpienia.

${ }^{24}$ ) „Il est courant dans les textes biblique qu'une famille ou un individu soit le symbole d'un group important..." - L. cit., s. 120.

Teorię eponimów omawia m. in. Ks. Cz. Jakubiec, dz. c., s. 47 nn.

25) Tamże, s. 118. 
zwłaszcza w wypadkach grożącego niebezpieczeństwa i w czasie walk. (Również ostrakon z Lakhisz mówi o takich sygnałach świetlnych). Otóż i ten szczegół znany nam jest już ze St. T.: Sędz 20, 38. 40; Jer 6, 1; Ez 17, 9 n.

Tylekroć piętnowana na kartach St. T. wiara w wróżbiarstwo właściwa ludom pogańskim, z którymi stykał się Izrael, szczególnie powszechna w Babilonii, znajduje w tekstach z Mari bardzo wyraźne potwierdzenie. Przed każdym ważniejszym przedsięwzięciem radzono się augurów i różnego pokroju wróżbiarzy, którzy zwłaszcza z wnętrzności zwierząt przepowiadali przyszłość. Hepatoskopia miała w rejonie Mari nadzwyczajne powodzenie i popularność (wątrobę uważano na Wschodzie za istotny organ myśli i uczuć). Zachowały się nawet specjalne modele wątroby sporządzone z gliny, które służyły najprawdopodobniej dla szkolenia nowych kadr wróżbiarzy ${ }^{26}$ ).

Mari było miastem politeizmu; kult Dagana (u Filistynów i Fenicjan czczony pod nazwą Dagona ${ }^{27}$ ), por. Sędz 16, 23; 1 Król 5, 2nn; 1 Kron 10, 10; 1 Mach 10, 84), bogini Isztar (w ziemi Kanaan znana i czczona jako Asztaroth, Astarta), Adada oraz plejady bóstw pomniejszych święcił tam triumfy. Panteon bogów różnych na terenie mezopotamskim świadczy wymownie, że monoteizm Abrahama i narodu, którego on jest patriarchą, nie mógł wyróść na takim gruncie.

Bóstwom tym poświęcone były na terenie Mari liczne świątynie. Wpośród odkopanych ruin wielu z nich najbardziej interesująca jest świątynia Dagona. Datuje się ona z początku drugiego tysiąclecia przed Chr., a znajduje się na miejscu innej,

26) Bliższe szczegóły zob. w Revue d’Assyriologie 35 (1938) 36 nn; 39 (1942-44) s. 82; por. Ks. J. Lelito, art. c., s. 33; Tenże, Swiatopogląd wschodni a biblijny, RBL 1 (1948) 145.

¿i) Zob. do kwestii Ks. J. Jelito, Bóstwa Fenicjan w świetle nowszych odkryć, RBL 5 (1952) 314 n. - Imię Dagana zachodzi też w imiomach spotykanych w Mari, np. Ishme-Dagan, Abdu-Dagan, Habdu-Dagan, SzamsziDagan, Ja-ab-bi-Dagan. - W nazwie miejscowości zachowanej w korespondencji z Mari: I-luum-Mu-lu-ukki zachodzi też imię Molocha (M-1-k); forma Muluk odpowiadałaby transkrypcji Moloch w LXX. Na wyraźne jednak ślady jego kultu w dokumentach z Mari dotąd nie natrafiono. 
jeszcze starszej. W ciągu wieków była szereg razy przebudowywana. Miała kształt długiego prostokąta i otoczona była posągami lwów ulanymi z brązu (ok. 40). Bramę okalały kamienne bloki z wydrążonymi otworami, w których umieszczano aszery. Odkopano również miejsce, na którym składano ofiary a nawet odnaleziono sam stół ofiarniczy. Teksty mówią istotnie o mnóstwie ofiar składanych bóstwom Mari. Władcy starali się ponadto zapewnić przychylność bóstw czczonych w innych miastach (por. Syria 20 (1939) $107 \mathrm{nn}$ ).

Wewnątrz świątyni znajdowała się sala z wysokimi ławkami przytykającymi do ściany. A. Parrot jest zdania, że były to raczej łoża niż ołtarze (te znajdowały się na zewnątrz) ${ }^{28}$ ). Uważa on, że mamy tu do czynienia z urządzeniem przeznaczonym dla specjalnej kategorii osób, które otrzymywały objawienia boskie przez sny. Odwołując się przy tym do faktu, że „,ten sposób objawień Bożych przez sny znany jest i u Izraela“, przytacza 1 Sam 3; 1 Król 3 nn oraz Iz 65, 4.

- Nie ulega wątpliwości, że Bóg mógł przez sen objawiać Swą wolę, co też niejednokrotnie czynił (por. i w N. T, Mt 1, $20 ; 2$, 12. 13. 19). Należy jednak jako sprostowanie do poglądu Parrot'a zaznaczył, że w Izraelu nie mamy do czynienia $\mathrm{z}$ oniromancją w sensie ,zawodowej“, stałej praktyki związanej jakby „oficjalnie“ z określoną kategorią ludzi przy świątyni, których zadaniem byłoby wyczekiwać na takie senne objawienia Boże. W 1 Sam, 3 (wołanie Samuela) i 1 Król 3, 5 nn (sen Salomona) chodziło tylko o sporadyczne, konkretne wypadki, w których Bóg chciał Swą szczególną interwencję podkreślić (zresztą na początku relacji pierwszego epizodu 1 Sam 3, 1 znajduje się znamienna uwaga, że (tego rodzaju) „Słowo Boże było rzadkie w tych czasach, widzenie Boże też nie było częste" 28a). Natomiast w tekście Iz 65, 4. ("...którzy mieszkaja wśród grobów, a w zborach bałwanów sypiaja...") chodzi o zabobonne nadużycia, które prorok zdecydowanie piętnuje na

${ }^{28)}$ Art. cyt., s. 119.

2sả) Tamże, s. 120. (Tłumaczenie 1 Sam 3,1 podaję wg ks. J. Kruszyńskiego). 
równi z innymi wystçpkami, które przypisać należy sporadycznym wpływom pogańskim.

Sanktuaria bóstw Isztar(at) i Ninni-Zaza zbudowane były według modeli architektonicznych domów mieszkalnych. W Mari bowiem również świątynia była domem, mieszkaniem boga.

Ołtarze - mimo iż okolice Mari obfitowały w kamień budowano z surowej cegły. Można by w związku z tym wskazać za A. Parrot'em na przepis wyrażony w księdze przymierza Ex 20, 24: „Wzniesiesz mï ołtarz z ziemi..." Zbieżność ta jest bardzo znamienna.

W sali wspomnianego już pałacu schody znajdowały siẹ z boku. - Wydaje się, że i ten szczegół związać można z instrukcją podaną w Ex 20, $\left.26^{29}\right)$.

W r. 1937 odkopano również karbowaną warstwe, przewidzianą bez wątpienia dla umieszczenia w niej tzw. massebot, betyli, a w listopadzie 1953 rzeczywiście znaleziono zupełnie nieuszkodzoną masebę. Skądinąd wiadomo, że maseby (betyle) i aszery, wspomniane też często na kartach Starego Test. stanowiły ważny element kultu kananejskiego. Na uwage zasługuje fakt, że maseba znaleziona w' Mari jest starsza niż podobne odkcpane w Ras Szamra, Gezer i Biblos.

Faktem niemałej wagi jest także, iż wykopaliska w Mari wykazały istnienie również w tej części Mezopotamii lzw. $_{\text {. }}$ ziggurat - wieży, jednej z tych, jakie budowano zwykle przy świątyniach na terenie Babilonii i Mezopatamii w ogóle. Wiarogodność relacji o ,,wieży Babel“ (Gen 11) zyskała już przedtem solidne poparcie $w$ fakcie odkopania ruin' takich potężnych ziggurat (zikkurat) w Borsippa (dziś. Birs-Nimrud, na południe od Babilonu) oraz w Babilonie samym świątynia Esagila z wieżą E-temen-anki) ${ }^{30}$ ). Odkopanie także w Mari takiej zig-

${ }^{29}$ ) .Nie będziesz wstępowat po stopniach do Mego ottarza, aby nie odkryła się nagość na tobie“. Parrot, s. 119.

$\left.{ }^{30}\right)$ Zob. F. Ceuppens, Quaestiones selectae ex historia primaeva, Marietti - Romae 1953, s. 339; L. H. Vincent, De la Tour de Babel au: Temple, Revue Bibl. 53 (1946) 404-406; R. Koldwey, Das wiedererstehende Babylon 4, Leipzig 1925, s. 179-193; P. Heinisch, Geschichte des A. T., Bonn 1950, 32. 
gurat na podobieństwo znanych nam z Babilonii, dominującej nad wszystkimi innymi budowlami miasta ma w związku z tym również swoją wymowę. Najwyższy punkt wzgórza (tell'u) w Mari przed jego odkopaniem, wynoszący $14,55 \mathrm{~m}$ pokrywał właśnie ruiny tej ziggurat.

Wreszcie na szczególną uwagę zasługuje okoliczność, że teksty z Mari ujawniają nam również istnienie tam pewnego rodzaju p rofetyz $\mathrm{m} \mathrm{u}$, w czym m. in. także A. Parrot dopatruje się wyraźnej paraleli do profetyzmu izraelskiego.

O tekstach ,prorockich“ z Mari pisał już przed paru laty v. Soden w czasopiśmie „Die Welt des Orients“ 5 (1950) 397-404. Najbardziej znamiennym wśród nich jest list IturAšdu, opublikowany w r. 1948 przez G. Dossin'a w „Comptes Rendus de l'Académie des Inscriptions et Belles Lettres (1948) 316 - 321, a szerzej omówiony przez niego w Revue d'Assyriologie 42 (1948) $125-148^{31}$ ). W liście tym spisanym na tabliczce klinowej mowa jest o osobie, która twierdzi że w mieście Terqa we śnie otrzymała od boga Dagona zlecenie w sprawie sporów z Bene-Jamina, o którym to poleceniu miała donieść ,gubernatorowi“, by ten z kolei powiadomił o tym króla. W ,proroctwie" tym chodzi więc widocznie o spontaniczną wieść udzieloną przez bóstwo a dotycząca ważnych spraw publicznych, państwowych. Bóstwo przemawia tu jako zwierzchnik do swego wasala.

Sa jeszcze ponadto trzy inne analogiczne teksty wydane w piśmie klinowym w serii „Textes cunéiformes du Louvre“ (tekst 90 ; t. 40 ; t. 78), a w transkrypcji z dodaniem tłumaczenia w "Archives Royales de.Mari" 2 (1941) 90; 3 (1948) 40 i 78.

W tekstach 40. i 78. mowa jest o mężu zwanym muhhûm -ekstatyku w służbie boga Dagona, który wieści bogów przekazywał królowi. W tekście 40. oświadcza ów muhhûm, że bóg domaga się ofiary pogrzebowej od króla Jahdunlim'a, a w tekście 78. bóg objawia wolę, by zbudowano bramę miasta. Do-

21) Komentarz do niego podal także W. v. Soden, Die Welt des Orients 5 (1950) 398 i M. Noth, The Bulletin of the John Rylands Library 33 (1950) $194-207$. 
kładniejsza jednak natura funkcji ekstazy u muhhûm’a nie jest bliżej sprecyzowana. - Tekst 90. jest niestety bardzo uszkodzony; z fragmentu można wywnioskować tylko tyle, że jakaś osoba rozmawia z bogiem oraz że chodzi o jakąś ceremonię religijną $\left.{ }^{32}\right)$.

W r. 1950 ukazała się w Anglii praca zbiorowa ,Studies in Old Testatment Prophecy" ${ }^{33}$ ), w której podany jest w transkrypcji i tłumaczeniu G. Dossin'a jeszcze jeden świeżo opracowany tekst ,prorocki" tabliczki klinowej z Mari ${ }^{33 a}$ ). Chodzi w nim o wyrocznie boga Adad w dwóch miastach: Kallassu i Halab. "Prorok" nosi tam tytuł „apillum", tj. (mąż) dający odpowiedzi“. Jest równiéz mowa o "apiltum“= (niewiasta) dająca odpowiedzi“. Pisarz redagujący ich słowa w odpowiednim liście do króla uważał za stosowne zaznaczyć, że zawsze baczną uwagę poświęcał ich słowom, gdy jeszcze przebywał w mieście Mari, jak i obecnie.

Mielibyśmy tu więc do czynienia z tzw. prorokami ,kultycznymi“ (prophetae ,cultuales"), przebywającymi stale przy poszczególnych sanktuariach, jak np. przy świątyniach wspomnianych miast Kallassu i Halab.

A więc oprócz zjawiska pewnego rodzaju proféyzmu, ,technicznego", wyuczonego - zachodziłby również profetyzm intuitywny, spontaniczny ${ }^{34}$ ).

W krótkiej ocenie powyższego stwierdzić należy, że istotnie na podstawie wykopalisk z Mari stoimy wobec faktu istnienia u Semitów — nie-Hebrajczyków jakiejś formy ,profetyzmu", odgrywającej niemałą rolę w sprawach państwowych. Chodziło w nim jednak raczej o pewnego rodaju, servitium

32) Por. R. Follet, De prophetismo semitico non hebraico adnotationes, Verbum D. 31 (1953), s. 29.

$\left.{ }^{3}\right)$ Zawiera szereg studiów dedykowanych juz w r. 1946 . znanemu bibliście Th. H. Robinson'owi dla uczczenia 65 lat jego życia.

32a) ,Une tablette inédite de Mari, interessante pour l'histoire ancienne du prophétisme sémitique* (Dz. cyt., s. 103-110).

${ }^{34}$ ) Wyrażenia przejęte $\mathrm{z}$ dzieła P. Amandry, La mantique apollinienne à Delphes, Paris 1950, 46. - Por. do kwestii J. T. Pedersen, The Rôle Played by Inspired Persons among the Israelites and the Arabs, w cyt. Studies in Old Test. Prophecy, s. 127-143. 
publicum", dzięki któremu w konkretnych wypadkach waznych dla kraju wzgl. dla życia i rozwoju szczepu badano wolę boga. „Profetyzm“ ten, którego zasadnicza treść ogniskowała się wokół wydarzeń politycznych, nie miał jednak charakteru doniosłego czynnika etycznego, wpływającego konstruktywnie na kształtowanie i podnoszenie poziomu religijnego i moralnego, który to element - obok faktycznego ustanowienia instytucji prorockiej w Izraelu przez Jahwę - prawdziwego Boga - stanowi istotę profetyzmu biblijnego.

Fundamentalne różnice pomiędzy tamtym ,profetyzmem““ środowiska politeistycznego a profetyzmem narodu wybranego rzucają się w oczy nawet przy zewnętrznym i ,czysto naukowym" już tylko badaniu ich wzajemnego do siebie stosunku, co przyznaje również A. Parrot ${ }^{35}$ ). A choć zewnętrznie może ten czy inny punkt wydaje się styczny (czego zresztą nie należy wyolbrzymiać), to jednak niedopuszczalnym i karkołomnym przeskokiem byłaby próba wyprowadzania na podstawie czysto zewnętrznych podobieństw tak wzniosłego profetyzmu biblijnego z form ,profetyzmu“ pogańskiego. Analogia non est genealogia!

Instytucja profetyzmu izraelskiego, będąca pochodzenia Boskiego, od samego początku nosi wybitny charakter sakralny, pełen namaszczenia, potęgi i żaru Bożego tchnienia craz religijno-etycznego dynamizmu i dlatego od zarania dziejów narodu była ona ,głosem jego sumienia“ ${ }^{36}$ ).

U jego podstaw - niby kamień węgielny znajdujemy słowa Jahwy: „Proroka im wzbudze spośród ich braci... i włoże słowa Moje w usta jego, i będzie mówił do nich wszystko, co mu przykaże..." (Deut 18, 18). Nadprzyrodzona misja powoływanych przez Jahwę na przestrzeni wieków proroków Izraela, ich wszechstronna i pod każdym względem dodatni wpływ wywierająca działalność, której wynikiem było, iż wzniosłe

$\left.{ }^{35}\right)$ „Il existe des différences fondamentales entre le prophétisme israélite et le prophétisme de Mari...", art. cyt., s. 120.

$\left.{ }^{36}\right)$ Zob. P. Heinisch, Geschichte des A. T., Bonn 1950, s. 175; s. $242-$ 249; Ks. J. Jelito, Działalność proroków Starego Testamentu, RBL 3 (1950), s. $122-136$. 
idee religijne małego narodu nie tylko nie rozpłynęły się w chaosie napierających nań zewsząd nưtów pogańskich, ale przeciwnie coraz bardziej się oczyszczały i. wzbogacały stając się stopniem przygotowawczym do chrześcijaństwa - nie ma precedensu i sprawia, że profetyzm Izraela jest jedynym w swoim rodzaju, a z tego względu - co przyznał już A. Jirku ${ }^{37}$ ) - rzeczywistej paraleli do tego, co stanowi istote jego i jądro, nie można odnaleźć w całej historii starożytnego Wschodu.

Pieniężno

KS. BERNARD WODECKI S. V. D.

\section{BEZŻENSTWO DLA KRÓLESTWA BOŻGO}

(Mt 19, 10-12)

Wyraźne i twarde stanowisko Chrystusa w kwestii roz. wodów, przywracajace małzeństwu w oparciu o powage Bogá rierozerwalność, zaskoczyło uczniów, którzy byli świadkami rozmowy Chrystusa $\mathrm{z}$ faryzeuszami. Po odejściu faryzeuszów według relacji $\mathrm{Mk}$ 10, 10 ,w domu“ uczniowie ponowili pytanie o rozwód, a Chrystus, podtrzymując swoje stanowisko, oświadczyłl, że każdy, kto opuszcza żonę i żeni się z inną kobietą cudzołoży i żona, która opuściła męża i wyszła za mąż za innego, cudzołoży ${ }^{1}$ ).

Wówczas uczniowie z naiwną prostotą, w której Buzy ") dopatruje się świadectwa wyjątkowego rozluźnienia obyczajów, panującego wśród najpobożniejszych Izraelitów, oświadczają: „Jeśli tak się ma sprawa człowieka z żoną, nie warto się żenić" ${ }^{3}$ ). Zdanie to, jak z jednej strony potwierdza, że uczniowie zrozumieli słowa Chrystusa o nierozerwalności mał-

37) Dz. cyt., s. 18; por. Ks. Arcybp J. Teodorowicz, Od Jahwy do Mesjasza, Poznań-Warszawa-Wilno-Lublin 1936, 225 nn; 259 nn; Ks. E. Dąbrowski, Glossy i odkrycia biblijne, Warszawa 1954, s. 65 n; A. Parenti, Synopis Introductionis Generalis in prophetas V. T., Romae 1941, s. $105-142$.

1) $\mathrm{Mk} 10,11-12$.

2) Ev. selon s. Matthieu, La Sainte Bible Pirot'a IX, Paris 1946, 250.

3) IIt 19, 10. 